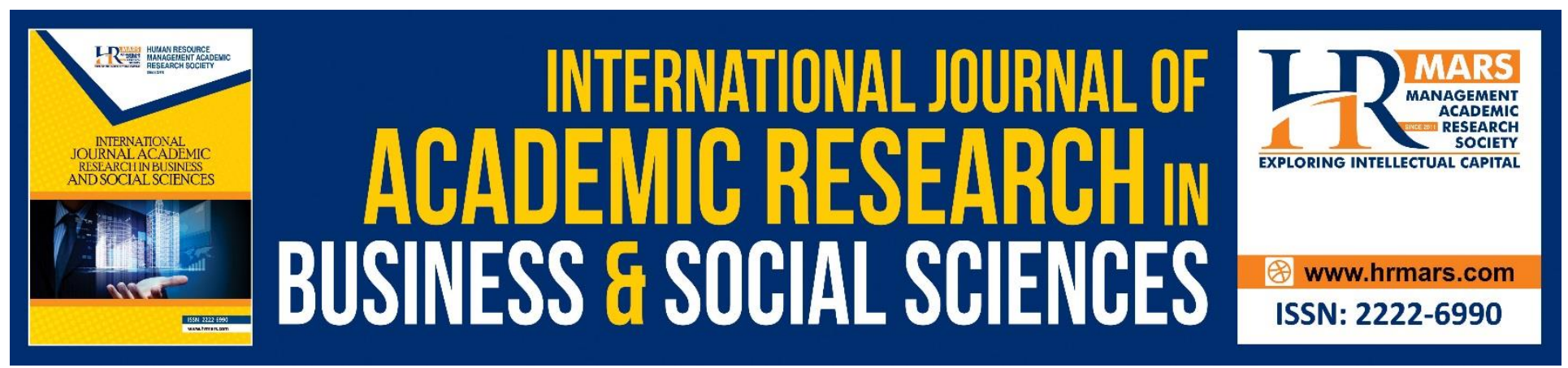

\title{
Challenges of Talent Development Implementation Among Non-Academician Staff in a Malaysian Higher Learning Institution
}

\begin{abstract}
Ahmad Amri Zainal Adnan, Omar Abdull Kareem, Ahmad Zainal Abidin Abd Razak
\end{abstract}

To Link this Article: http://dx.doi.org/10.6007/IJARBSS/v9-i3/5633

DOI: $\quad 10.6007 /$ IJARBSS/v9-i3/5633

Received: 06 March 2019, Revised: 29 March 2019, Accepted: 08 April 2019

Published Online: 11 April 2019

In-Text Citation: (Adnan, Kareem, \& Razak, 2019)

To Cite this Article: Adnan, A. A. Z., Kareem, O. A., \& Razak, A. Z. A. A. (2019). Challenges of Talent Development Implementation Among Non-Academician Staff in a Malaysian Higher Learning Institution. International Journal of Academic Research in Business and Social Sciences, 9(3), 102-112.

Copyright: @ 2019 The Author(s)

Published by Human Resource Management Academic Research Society (www.hrmars.com)

This article is published under the Creative Commons Attribution (CC BY 4.0) license. Anyone may reproduce, distribute, translate and create derivative works of this article (for both commercial and non-commercial purposes), subject to full attribution to the original publication and authors. The full terms of this license may be seen

at: http://creativecommons.org/licences/by/4.0/legalcode

Vol. 9, No. 3, 2019, Pg. 102 - 112

http://hrmars.com/index.php/pages/detail/IJARBSS

JOURNAL HOMEPAGE

Full Terms \& Conditions of access and use can be found at http://hrmars.com/index.php/pages/detail/publication-ethics 


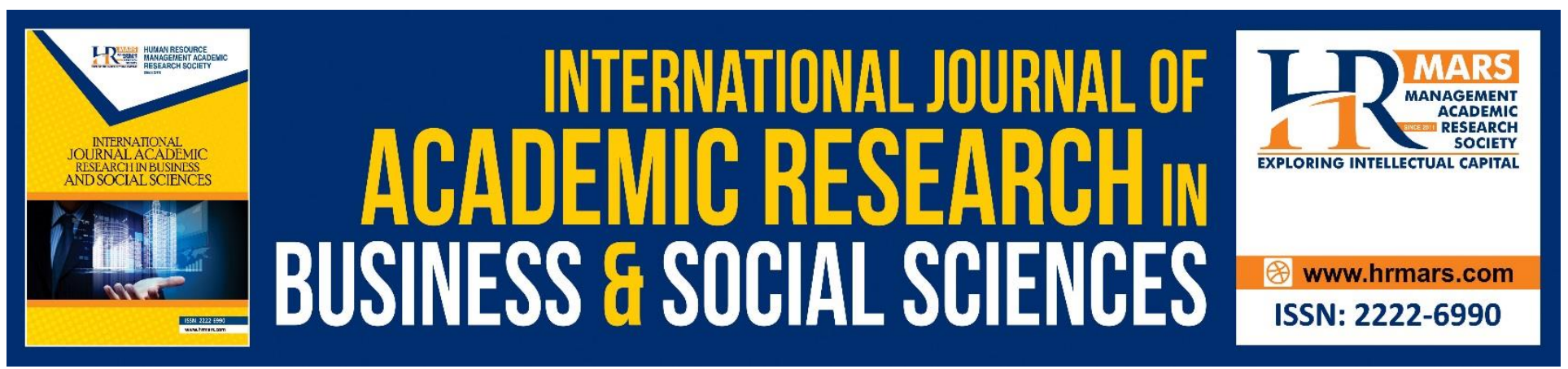

\title{
Challenges of Talent Development Implementation Among Non-Academician Staff in a Malaysian Higher Learning Institution
}

\author{
Ahmad Amri Zainal Adnan \\ Department of Business Management \& Entrepreneurship, Faculty of Management \& Economics, \\ Universiti Pendidikan Sultan Idris, Malaysia. \\ Email:a.amri@fpe.upsi.edu.my
}

\section{Omar Abdull Kareem}

Department of Business Management \& Entrepreneurship, Faculty of Management \& Economics, Universiti Pendidikan Sultan Idris, Malaysia.

Email: omar@fpe.upsi.edu.my

\section{Ahmad Zainal Abidin Abd Razak}

Department of Business Management \& Entrepreneurship, Faculty of Management \& Economics, Universiti Pendidikan Sultan Idris, Malaysia.

Email: ahmadzainal@fpe.upsi.edu.my

\begin{abstract}
While research and implementation on the part of the industry has proven that the development of the right talent can improve productivity and provide competitive advantage, the higher education institution is still slow to act and seize the opportunity. Public universities in Malaysia are no exception in this regard and has only begun to design a more systematic talent development plan recently although the relevant circulars have been issued by the government since 2006 . The case study aims to identify the problems that arise in the planning and implementation of talent development strategies at one of the public university, as well as highlighting recommendations to enable it to compete with other higher education institutions. The case study uses a qualitative approach such as interviews and analysis of official documents. Respondents consist of top management and staff involved with the implementation of the plan. The result of this study found that four (4) major obstacles to the development of talent in the public university are Management, Structural, Behavioral and Environmental factors. While still at the development stage, the university needs to ensure that planning is strategically driven and in line with the university's missions.
\end{abstract}


INTERNATIONAL JOURNAL OF ACADEMIC RESEARCH IN BUSINESS AND SOCIAL SCIENCES

Vol. 9, No. 3, March, 2019, E-ISSN: 222 2-6990 @ 2019 HRMARS

Keywords: strategy, challenges, talent development, higher education, competitive advantage.

\section{Introduction}

Lynch (2007) has raised his concerns over higher education institutions capability of producing quality graduates but not using the same knowledge to develop their staff. According to him, higher education institutions should have the advantage in the implementation of talent management as it is an institution that develops the related knowledge. Hence, he suggested that higher education institutions review their organization's policies and cultures to be seen as an entity that leads the development of human capital in the society.

Higher education institutions that develop talent from within their organizations to become future leaders have advantages over institutions that do not develop talent and successors from within (Mackey, 2008). The advantage of building talents from within the organization can ensure the continuity of the organization's goals. Talent management that meets the specific needs of an organization such as its values, culture and environment is important to achieve long-term goals (Clunies 2008; Edward, 2008). However, according to Clunies (2008), most higher education institutions are slow to adapt to best practices in corporate management. Lynch (2007) also pointed out that higher education institutions lag behind other industries in talent management practices.

The talent management practices implemented do not meet the definition of 'talent management' due to lack of elements and systematic approaches in staff career development such as developing specific leadership competencies and career improvement strategies (Riccio, 2010). In a study conducted in 2013 found that only 1 out of every 4 organizations integrates talent development practices with strategic objectives of the organization (Ashkenas, 2016). Hence, top management plays a critical role in ensuring the success of talent development in their respective organizations.

The study conducted by Aon Hewitt (2012) on 80 higher education institutions in the United States found that only $48 \%$ of higher education institutions use a systematic performance management process, $11 \%$ higher education institutions use a replacement plan to fill vacancies in the highest positions, $36 \%$ of higher education institutions place the talent development agenda as the 5 most important strategic priorities of the institutions.

In Malaysia, the same situation has hit public universities where strategic talent management has only begun as an agenda in university management over the past 3 years. The National Higher Education Strategic Plan (PSPTN) Phase 1 (2007-2010), for example, does not outline a specific talent management strategy of higher education institutions until the review was conducted and PSPTN Phase 2 (2011 - 2015) was implemented. Only in 2015, when the 2015-2025 (Higher Education) Malaysian Education Development Plan (PPPM) was issued by the government, a clearer direction and strategy to develop talent can be observed under Agenda 2: 'Talent Excellence'. This strategy was then extended to all public universities as a guideline for coordination.

The chosen public university in this study has only begun to design a talent development plan in 2016 although the relevant circulars have been issued by the government since 2006. This phenomena is also common among most of the public universities in Malaysia. Why exactly causes the late development are yet to be studied. This case study aims to identify the problems that arise in the planning and implementation of talent development strategies at the university, as well as 
INTERNATIONAL JOURNAL OF ACADEMIC RESEARCH IN BUSINESS AND SOCIAL SCIENCES

Vol. 9, No. 3, March, 2019, E-ISSN: 222 2-6990 @ 2019 HRMARS

highlighting recommendations to enable it to compete with other higher education institutions, and come out as top talent developer.

\section{Literature Review}

There is no definite and agreed definition of what is meant by talent management. However, the definition of talent management consistent with most previous studies is the strategic process by which the organization plans and meets the talent requirements for strategic positions of the organization (Cappelli \& Keller, 2014). Talent management has been a concern of academics and industries because of the notion that it is the key to competitive advantage (McDonnell, Collings, Mellahi, \& Schuler, 2017) and driver of organizational success (Beheshtifar, Yossefi Nasab, \& NekoieMoghadam, 2012).

Undeniably, competitive advantage (by retaining the best talents) is required by higher education institutions and efficient talent management practices are one of the methods to gain the competitive advantage. Previous study also showed that core principles of talent management system have a significant impact on competitive advantage specifically in the cellular communications companies (Almaaitah, Harada, \& Sakdan, 2015). In general, managing talents efficiently should bring the same conclusion in other industries.

The importance of systematic talent management has become increasingly significant in the rapid technological change of the $21^{\text {st }}$ century and the difficulty of acquiring talents that can contribute to organizational strategy effectively. Hence, according to McDonnell (2011) talent management will continue to be a major challenge for organizations in the next few decades.

Systematic talent management can be carried out either using an inclusive or exclusive approach (Cappelli \& Keller, 2014). An inclusive approach means the entire staff within the organization is developed on the basis of their respective strengths. While an exclusive approach looks at talent as only part of the staff contributes significantly to organizational needs and strategies. This approach coincides with the theory of optimizing the source (Majumdar, 1998).

Several factors contribute to the successful implementation of talent management in organization. Marjan Tafti, Mahmoudsalehi, \& Amiri (2017) highlighted three (3) success factors regarding talent management implementation. There are structural success factors, environmental success factors and managerial success factors. Structural factors include elements and physical conditions in the organization; environmental factors are related to the external forces that surround the organization; and the managerial factors are related to human relations in the organization. Success of the succession plan was also found to have a relationship with the leadership (Ahmad, Mohamed, \& Manaf, 2017).

Marjan Tafti, Mahmoudsalehi, \& Amiri (2017) categorizes the major obstacles to talent management as structural, environmental, behavioral and management in automotive industries. Whether the same obstacles exist in higher education institutions have yet to be identified. The challenge of developing talents also does not depend solely on the implementer but also depends on the existing talent. Coulson-Thomas (2012) notes that some talents are difficult to manage because of their own attitudes when they are in the talent pool. On the other hand, Ross (2013) emphasized that employers need to understand the strengths and capabilities of each staff as well as create a 
conducive atmosphere for utilizing existing talents, rather than classifying staff to potential productive and potentially unproductive.

Impact of effective talent management can be observed through increased job satisfaction and decreased of employee turnover. According to Dixit \& Arrawatia (2018), talent management strategies are positively related to job satisfaction. While Isfahani \& Boustani (2014) found that there was a positive relationship between talent management and employee retention among employees at Isfahan University.

\section{Methodology}

Qualitative approach was chosen for this study to get an in-depth understanding of the reasons behind the problems that arise. This study uses a case study method as it suited to the goal to investigate a phenomenon in a real-life situation. Data were obtained through two methods. The first method is through interviews with selected staff, selectively and represent the top management and staff who are involves with the development of talent. Thus, purposive convenience sampling was use, meaning the respondents were selected based on their willingness to take part in the data collection process and the relevance of their contributions. A total of eight (8) respondents were interviewed in person, one after the other until data saturation was reached. Respondents were chosen based on their experience and roles in the organization concerning talent development.

As can be seen from Table 1, the majority of the respondents were female (62.5\%). All respondents have been working at the university for at least 10 years. Two of the respondents (25\%) are top management and have a say in decision makings in the organization. $37.5 \%$ (3 respondents) are in the middle tier of management and also held positions in the Human Resource Department. They are actively involved in the talent development plan. Another $37.5 \%$ are also in the middle tier of management, but received trainings or participated in talent development programs conducted by the university.

Table 1: Respondents' demographics

\begin{tabular}{cccl}
\hline Respondents & Gender & Tenure (years) & \multicolumn{1}{c}{ Job Level } \\
\hline 1 & Female & 16 & Top management \\
2 & Female & 12 & Top management \\
3 & Female & 16 & Mid-management (HRD) \\
4 & Female & 17 & Mid-management (HRD) \\
5 & Male & 10 & Mid-management (HRD) \\
6 & Male & 17 & Middle management \\
7 & Female & 11 & Middle management \\
8 & Male & 20 & Middle management \\
\hline
\end{tabular}

Respondents were given semi-structural questions based on Marjan Tafti, Mahmoudsalehi, \& Amiri (2017) concepts regarding the four critical challenges in talent development. The purpose of the interviews was to gain a more profound meaning by allowing for concepts to emerge from the results. The respondents were requested to delineate their experiences where talent management is concerned. The questions sought to determine the understanding of the respondents on talent 
management, the implementation of programs, challenges faced, effectiveness and how talent management could contribute to organizational success in the long run.

Audio recordings of the respondents' responses were transcribed into text documents. Thematic analysis was used to uncover the associations that existed across the phenomena. Coding of themes and sub-themes were generated and supported with verbatim quotes. The data from the interviews were inductively analyzed, and interpreted to the concepts, categories and themes (thematic analysis) manually.

The second method for collecting data is through official documents of related departments such as minutes of meetings, reports, statistics and so on. Data from the documents were interpreted in terms of commitment, planning and implementation linkages, performance comparisons, training structures and financial impact. These two methods of data collection provide the validity of the study through triangulation of data.

\section{Findings}

Based on the frequencies of the codes in the transcript of the interview, three codes namely 'leadership' (21), 'planning' (14) and 'priority' (12) dominated the discussion of talent development issues in the university. These initial codes were later on labelled under several themes. The theme construction phase (Vaismoradi et al. 2016) includes classifying, comparing, labelling, translating and defining the codes. Similar themes then were put under the same categories based on Marjan Tafti, Mahmoudsalehi, \& Amiri (2017) conceptual of the challenges in talent management.

The summary of the analysis found that the main obstacles in the development of talent in particular between 2006 to 2016 is as in Table 2:

Table 2: The main obstacle factors in the implementation of talent development.

\begin{tabular}{ll}
\hline Management & Lack of commitment and support from previous top management. \\
& $\begin{array}{l}\text { There was no commitment to strategic planning (related to talent } \\
\text { development). }\end{array}$ \\
\hline & Did not gave priority to the development of talent. \\
\hline Lack of knowledge about how to develop of talents. \\
\hline Less prudent approach. \\
\hline & $\begin{array}{l}\text { There is lack of knowledge and skills to carry out talent development } \\
\text { programs. }\end{array}$ \\
\hline Focus on administrative processes rather than talent development. & Difficult to develop the talent system. \\
\hline Individual's attitude in the organization: \\
& - complacent \\
& - reluctant to change \\
& - reactive \\
& - not interested \\
\hline Organizational culture: \\
- territorial (unhealthy competition) \\
- lack of innovation \\
\hline Environment & There is no monitoring and enforcement by the government. \\
\hline
\end{tabular}


Management factor seems to be the main obstacle that was faced by the organization between 2006 until 2016. Commitment, priority, knowledge and ability to align talent development with strategic organization goals are some of the themes emerged from the interviews. Based on the frequencies of the coding, leadership was the most talk about issue in the interview sessions. The university's leadership during the 10 years absence of a talent management plan, fail to give support and commitment to a systematic talent development plan. These direct confessions from the respondents pointed out the underpinning cause:

We know that the policy can be done easily, but when it comes to implementation, to me, it will depends on the top management; how far he (Registrar) sees things (the talent development plan) as a matter of importance. (Respondent 1)

And:

There's an obstacle from the top management ... not stopping us, but we're not getting support from ... the Registrar at that time. (Respondent 3)

And:

I blame the previous management, for not taking seriously of the matter, non-sensitive and not giving priority to talent management plan. (Respondent 5)

The structural factor highlighted the lack of resources that is needed to plan and execute the talent development process. These resources include knowledgeable human resource managers and system experts as elaborated by the respondents:

Actually its not that we didn't do it. But the proof is not available... we realized that we have done something about it but not in a structured way, no one took responsibility, when to do it? who will monitor it? (Respondent 2)

And:

We just have to have a really good team to ensure that things workout. (Respondent 4)

And:

Because you have to develop a system when it comes to such an assessment and it's not easy to do. (Respondent 4)

On the behavior factor, it could be divide into two sub-factors: individual's attitude and organizational culture. Individual's attitudes include reluctancy to change in the organization when 
INTERNATIONAL JOURNAL OF ACADEMIC RESEARCH IN BUSINESS AND SOCIAL SCIENCES

Vol. 9, No. 3, March, 2019, E-ISSN: $2222-6990$ C 2019 HRMARS

the talent development plan was initially introduced. These factors can be detected from the respondents' answers:

I have to force them at first, and knowing our culture, there's a lot of problems. (Respondent 1)

And:

To me the most significant is culture. Culture because we're in a comfort zone. (Respondent 1)

Last but not least, environment factor also played an important role in the success of a talent development plan. Monitoring and enforcement from the university and government will determine the pace of the process. This was stressed by Respondent 3:

Regarding the circular, the government issued the circular but they did not monitor whether we execute it or not.

Based on respondents' feedback and reviewed documents, the status and implementation of the talent development plan are as per Table 3. However, the effectiveness of implementation can't be determined because it is still at the planning and development stage.

Table 3: Status and planning of talent development plan.

\begin{tabular}{ll}
\hline Year & Planning \\
\hline $2016-2017$ & Policy and procedures development \\
2018 & Profiling and system / tool development \\
2019 & Assessment and revision \\
2020 & Full implementation \\
\hline
\end{tabular}

The effectiveness of the talent development plan can't be measured accurately as it is still in its early stages and there has been no benchmark for the progress of its construction, as explained by Respondent 6:

When it comes to effectiveness, we usually based on our perceptions. There is no report (of effectiveness) that can support the development plan.

And:

In term of proper assessment, we don't have. (Respondent 3)

As full implementation is expected to only be carried out in 2020, therefore, the effectiveness of the implementation remains undetermined. However, respondents acknowledge the lack of 
INTERNATIONAL JOURNAL OF ACADEMIC RESEARCH IN BUSINESS AND SOCIAL SCIENCES

Vol. 9, No. 3, March, 2019, E-ISSN: 222 2-6990 ¿ 2019 HRMARS

knowledge and skills in implementing the plan contributes to the slow progress, as expressed by Respondent 3:

We don't know how to do, so we have to find someone who knows how to do it.

From the perspective of gaining competitive advantage through the implementation of the talent development plan, it seems that management needs to make a strategic alignment to ensure the plan to be implemented is unique and difficult to duplicate by other competitors. Data obtained indicate that the management does not put emphasis and focus on making talent development plans as a tool to gain advantage over other competitors. This can be conclude from the respondents' feedbacks which does not resemble a solid competitive advantage solution, but more to be at par with other public universities.

\section{Discussion}

The study found that the major obstacle factors in the implementation of effective talent development plan at the university could be categorized into four (4) namely Management, Structural, Behavior and Environment. This finding is in line with the model proposed by Marjan Tafti, Mahmoudsalehi, \& Amiri (2017). Based on the findings, it can be concluded that the model proposed by Marjan Tafti, Mahmoudsalehi, \& Amiri (2017) is applicable to other settings and the major obstacles faced by industries are very much similar. Knowing this, experts and practitioners should focus on the solutions on how to overcome these obstacles.

The researcher proposes several steps to ensure the talent development plan can be carried out as planned and more efficiently based on the four categories mentioned above: the top management should be the main driver of talent development by providing direction and monitoring of its development; building talent development as one of the priorities in university strategic plans; management needs to communicate the importance and talent development needs throughout the organization. As reported by Rudhumbu (2014), talent management strategies that were implemented in most higher education institutions in Botswana were ineffective due to lack of prioritization on the part of institutional leadership. Hence, Malaysian higher education institutions must make talent management as their top priority.

Human Resource (HR) managers and academicians should work together to formulate the best solutions and strategies to develop talents considering the lack of knowledge and expertise among HR managers and the lack of hands on experience of academicians in managing talents. Furthermore, to catalyse and manage the change in employee's behavior, the organizational culture must be align towards becoming a learning organization that focuses on learning and development. As Azman, Sirat, \& Pang (2016) posited, "a major change of mindset among Malaysians is truly needed" to develop a more creative and talented human resources.

The researcher also suggested that the implementers have a more comprehensive chart of the 2018-2020 talent development plan for planning and monitoring more effectively. The university employees can also be formed to become its assets and source of competitive advantage, provided that the goals of talent development is clear and the plans are unique, thus difficult to be duplicate by other universities. The recommendations suggested will put back the planning and 
INTERNATIONAL JOURNAL OF ACADEMIC RESEARCH IN BUSINESS AND SOCIAL SCIENCES

Vol. 9, No. 3, March, 2019, E-ISSN: 222 2-6990 ¿ 2019 HRMARS

implementation on track, and help other higher learning institutions to plan their talent development with more efficiency.

\section{Acknowledgments}

This research is funded by Universiti Pendidikan Sultan Idris Research Grant (2017-0163-106-01).

\section{References}

Ahmad, R. B., Mohamed, A. M. bin, \& Manaf, H. B. A. (2017). The Relationship Between Transformational Leadership Characteristic and Succession Planning Program in the Malaysian Public Sector. International Journal of Asian Social Science, 7(1), 19-30. Retrieved from https://doi.org/10.18488/journal.1/ 2017.7.1/1.1.19.30

Aon Hewitt. (2012). 2012 Higher Education Survey: The State of Human Resource Effectiveness. Retrieved from http://www.aonhewitt.com

Ashkenas, R. (2016). You Can't Delegate Talent Management to the HR Department. Harvard Business Review, 1-2, September. Retrieved from https://hbr.org/2016/09/you-cant-delegatetalent-management-to-the-hr-department.

Azman, N., Sirat, M., \& Pang, V. (2016). Managing and mobilising talent in Malaysia: issues, challenges and policy implications for Malaysian universities. Journal of Higher Education Policy and Management, 38(3), 316-332. Retrieved from https://doi.org/10.1080/1360080X.2016.1174406.

Beheshtifar, M., Yossefi Nasab, H., \& NekoieMoghadam, M. (2012). Effective Talent Management: A Vital Strategy to Organizational Success. International Journal of Academic Research in Business and Social Sciences, 2(12), 227-234.

Cappelli, P., \& Keller, J. (2014). Talent Management: Conceptual Approaches and Practical Challenges. Ssrn. Retrieved from https://doi.org/10.1146/annurev-orgpsych-031413-091314

Clunies, J. P. (2007). Benchmarking succession planning and executive development in higher education: Is the academy ready now to employ these corporate paradigms? Retrieved from http: //www.academicleadership.org

Coulson-Thomas, C. (2012). Talent management and building high performance organisations. Industrial and Commercial Training, 44(7), 429-436.

Dixit, S., \& Arrawatia, M. A. (2018). The Impact of Talent Management on Job Satisfaction and Employee Performance in Public Sector Banks of Rajasthan, International Journal of Creative Research Thoughts, 6(1), 425-435. 
INTERNATIONAL JOURNAL OF ACADEMIC RESEARCH IN BUSINESS AND SOCIAL SCIENCES

Vol. 9, No. 3, March, 2019, E-ISSN: 222 2-6990 ¿ 2019 HRMARS

Edwards, B. (2008). A customized approach to talent management at the University of Pennsylvania. CUPA-HR Journal, 59(1), 2-7.

Lynch, D. (2007). Can higher education manage talent? Retrieved from http://www.insidehighered.com

Mackey, J. A. (2008). Community college leadership succession: Perception and plans of community college leaders (Doctoral dissertation). Retrieved from Universiti Arizona, AS.

Majumdar, S. K. (1998). On the utilization of resources: perspectives from the U.S. telecommunications industry. Strategic Management Journal, 19(9), 809-831.

McDonnell, A. (2011). Still Fighting the "War for Talent"? Bridging the Science Versus Practice Gap. Journal of Business and Psychology, 26(2): 169-173. Retrieved from https://doi.org/10.1007/s10869-011-9220-y

McDonnell, A., Collings, D. G., Mellahi, K., \& Schuler, R. (2017). Talent management: a systematic review and future prospects. European Journal of International Management, 11(1), 86-128. Retrieved from https://doi.org/10.1504/EJIM.2017.10001680

Riccio, S. (2010). Talent Management in Higher Education: Developing Emerging Leaders Within the Administration at Private Colleges and Universities (Doctoral dissertation). Retrieved from University of Nebraska - Lincoln, AS.

Ross, S. (2013). How definitions of talent suppress talent management. Industrial and Commercial Training, 45 (3): 166-170.

Rothwell, W. J., Chee, P. \& Ooi, J. (2016). The Leader's Daily Role in Talent Management: Maximizing Result, Engagement and Retention. Singapore: McGraw Hill.

Rudhumbu, N. (2014). Implementation of Talent Management Strategies in Higher Education : Evidence from Botswana. Journal of Human Ecology, 1(1), 86-99.

Scullion, H. \& Collings, D. G. (Ed.) (2011). Global Talent Management. New York : Routledge.

Tafti, M. M., Mahmoudsalehi, M., \& Amiri, M. (2017). Critical success factors, challenges and obstacles in talent management. Industrial and Commercial Training , 49(1), 15-21. Retrieved from https:// doi.org/10.1108/ICT-05-2016-0036

Vaismoradi, M., Jones, J., Turunen, H., \& Snelgrove, S. (2016). Theme development in qualitative content analysis and thematic analysis. Journal of Nursing Education and Practice, 6(5), 100110. 